\title{
Anesthetic management of allograft reconstruction following hemipelvectomy: A series of 12 cases
}

\section{Hemipelvektomi sonrası allogreftle rekonstrüksiyonda anestezi yönetimi: 12 olgu serisi}

\author{
Tugba Askin $^{1}$, Süheyla Ünver ${ }^{1}$, Mensure Kaya ${ }^{1}$, Dilek Kalayci ${ }^{1}$, Kubra Kutay Yazici ${ }^{2}$, Ahmet Fevzi \\ Kekeç $^{3}$, Bedii Safak Gungor ${ }^{4}$ \\ ${ }^{1}$ Dr. Abdurrahman Yurtaslan Onkoloji Eğitim Ve Araştırma Hastanesi, Anesteziyoloji Ve Reanimasyon Kliniği \\ ${ }^{2}$ Bağcılar Eğitim Ve Araştırma Hastanesi, Anesteziyoloji Ve Reanimasyon Kliniği \\ ${ }^{3}$ Dörtyol Devlet Hastanesi, Ortopedi Ve Travmatoloji Kliniği \\ ${ }^{4}$ Dr. Abdurrahman Yurtaslan Onkoloji Eğitim Ve Araştırma Hastanesi, Ortopedi Ve Travmatoloji Kliniği
}

Dergiye Ulaşma Tarihi: 06.08.2019 Dergiye Kabul Tarihi: 15.01.2020 Doi: 10.5505/aot.2020.53215

\section{ÖZET}

GİRIŞ ve AMAÇ: Literatürde hemipelvektomi anestezi yönetimi hakkında karşılaşılan çok fazla bilgi 5 bulunmamaktadır. Bu çalışma ile nadiren yapılan hemipelvektomi sonrası allogreftle rekonstrüksiyon anestezi yönetimine dikkat çekmek istiyoruz.

YÖNTEM ve GEREÇLER: Aralık 2010- Şubat 2014 tarihleri arasında internal hemipelvektomi ve allogreftle rekonstrüksiyon cerrahisi yapılan hastalarda dosya incelemesi retrospektif olarak yapıldı. Yaş, cinsiyet, ASA, ek hastalık, uygulanan anestezi yöntemi, preoperatif ve postoperatif hemoglobin değeri, intraoperatif kanama miktarı, intraoperatif verilen mayi ve kan transfüzyon miktarı, operasyon süresi, yoğun bakım ve hastanede kalış süreleri, mortalite-morbidite oranları değerlendirildi.

BULGULAR: Bu çalışmada 12 hasta dosyası değerlendirildi. Hastalar ortalama yaşları 37,5 $\pm 14,6(10-57$ arasında) idi. 10 hastaya genel anestezi, 2'sine kombine spino-epidural (KSE) anestezi uygulandığ1 görüldü. Ortalama intraoperatif kanama miktarı $2346 \pm 1504 \mathrm{ml}$ idi. Sıv1 yönetimi ile ilgili olarak ortalama $3916 \pm 1673 \mathrm{ml}$ kristalloid, $812 \pm 441 \mathrm{ml}$ kolloid, $1479 \pm 856 \mathrm{ml}$ eritrosit süspansiyonu ve $350 \pm 302 \mathrm{ml}$ TDP intraoperatif kullanıldı. Ortalama cerrahi süre 273,8 $\pm 69 \mathrm{dk}$, postoperatif yoğun bakımda kalış süresi 38,0 $\pm 34,6$ saat, hastanede kalış süresi 25,4 \pm 21,4 gün idi. 12 hastanın 5'i anestezi dışı sebeplere bağlı olarak operasyondan birkaç ay sonra kaybedildi.

TARTIŞMA ve SONUÇ: Hemipelvektomi sonrası allogreftle rekonstrüksiyon cerrahisi yapılan hastaların, tam bir anestezi öncesi viziti ve bütün perioperatif dönemi kapsayan yakın takibi öneriyoruz.

Anahtar Kelimeler: Anestezi, hemipelvektomi, allogreft

\section{ABSTRACT}

INTRODUCTION: There are not many reports encountered regarding anesthesia management of hemipelvectomy in the literature. We would like to call attention to anesthetic management of allograft reconstruction following hemipelvectomy with this study, which is rarely performed.

METHODS: The records of patients who underwent internal hemipelvectomy between December 2010 and February 2014 were retrospectively evaluated. The age, gender, ASA, comorbidity, anesthesia method applied, hemoglobin values, intraoperative amount of bleeding, amount of intraoperatively administered fluid and blood transfusion, duration of operation, intensive care stay and hospitalization, mortality and morbidity rates were analyzed.

RESULTS: 12 patients were evaluated in this study. The mean age of all patients was 37,5 $\pm 14,6$ (range between 10 and 57). The anesthetic management was provided by general anesthesia for ten patients and combined spinalepidural (CSE) anesthesia for two patients. The mean intraoperative amount of bleeding was $2346 \pm 1504 \mathrm{ml}$. With regards to fluid management, $3916 \pm 1673 \mathrm{ml}$ crystalloids, $812 \pm 441 \mathrm{ml}$ colloids, $1479 \pm 856 \mathrm{ml}$ erythrocyte suspension, and $350 \pm 302 \mathrm{ml}$ fresh frozen plasma were infused during intraoperative period. The mean duration of surgery, intensive care stay and hospitalization were $273.8 \pm 69$ minutes, $38.0 \pm 34.6$ hours and $25.4 \pm 21.4$ days, respectively. Five patients out of 12 were died a few months after the surgery, but the anesthetic management was not found to related with the mortality. 
DISCUSSION AND CONCLUSION: We recommend a perfect pre-anesthetic visit and close follow up including whole perioperative period for the patients undergoing allograft reconstruction surgery following hemipelvectomy.

Keywords: Anesthesia, hemipelvectomy, allograft

\section{INTRODUCTION}

Hemipelvectomy procedures are widely preferred as a surgical treatment option for pelvic tumors. Reconstructive surgery by using bone allograft is a surgical reconstruction technique following hemipelvectomy $(1,2)$. The surgical treatment of pelvic tumors is prone to many complications because of the complex anatomy of pelvis, which has a close relationship with neurovascular structures and it is not always easy to access adequate surgical margins during surgery (3).

Since hemipelvectomy procedures are technically difficult, a large tissue trauma secondary to surgery leads to a major blood loss, which is also facilitated by the administration of preoperative neoadjuvant chemotherapy or radiotherapy, almost a current standard for pelvic tumors $(4,5)$. The systemic inflammatory response due to major surgery along with a massive blood transfusion and an extensive fluid loss raise many postoperative problems including organ failures (6). Therefore, the anesthetic management for hemipelvectomy requires careful evaluation, close follow up and monitoring of the patient throughout the whole perioperative period.

Although there is a large number of studies published in the literature $(7,8)$ regarding the surgical technique and surgical complications of hemipelvectomy, not many reports are presented on anesthetic management of this procedure. These kinds of surgeries need expert surgical approach and can only be performed in a small number of medical centers. The prediction and prevention of problems associated with anesthesia that might be encountered intraoperatively is another challenging problem. The aim of our retrospective study is to provide input to the current literature by presenting our anesthesia experiences of patients undergoing allograft reconstruction following internal hemipelvectomy.

\section{MATERIAL METHOD}

This study was a retrospective study at a single centre, performed with approval by the ethical board (Dr. Abdurrahman Yurtaslan Oncology Training and Research Hospital Ethics Committee protocol no: 2014-2-83).The medical records of patients, who underwent internal hemipelvectomy and extremity preserving pelvic resection and fresh frozen massive pelvic allograft bone transplantation, due to pelvic tumors between December 2010 and February 2014, were retrospectively analyzed.The medical records of patients The parameters analyzed were age, gender, American Society of Anesthesiologists scores (ASA), comorbidity, histopathological analysis and stage of the lesion, the anesthesia method applied, preoperative and postoperative hemoglobin values, intraoperative amount of bleeding, amount of intraoperatively administered fluid and blood transfusion, urine amount, duration of operation, the number of reoperations and neoadjuvant chemotherapy sessions, the duration of intensive care and hospital stay, mortality and morbidity rates. Data were obtained from the medical records of the patients and from the anesthesia and intensive care follow-up forms.

Statistical evaluation was performed using SPSS 16.0 package program (SPSS Inc., Chicago, U.S.A) and the following tests were conducted: Normal distribution of the variables was tested with visual (histogram and probability graphics) and analytic methods (Kolmogorov- Smirnov Shapiro-Wilk tests). Statistical analysis data were expressed as mean \pm standard deviation, median (25-75\%), (MinMax), and $n(\%)$. Level of significance was 
accepted as $\mathrm{p}<0.05$. Qualitative variables were evaluated using Chi-square test or Fisher's exact Chi-square test.

\section{RESULTS}

All patients were preoperatively evaluated one to two weeks prior to the scheduled day of operation. Preoperatively administered chemotherapy and radiotherapy were recorded in the anesthesia preoperative evaluation form, in addition to systems questioning and examinations, which are required for all other types of surgery. For one patient medical oncology and hematologyconsultation were requested, for neutropenia and thrombocytosis, respectively in addition to the preoperative standard laboratory tests.

The perioperative data of the 12 patients included in the study is summarized in Table 1. The amounts of fluid and blood products replaced intraoperatively,duration of operation are also demonstrated in Table 1. Mean preoperative and postoperative hemoglobin $(\mathrm{Hb})$ values and amount of intraoperative bleeding were $12.0 \pm 2.1 \mathrm{~g} \mathrm{dL}-1$, $10.5 \pm 1.4 \mathrm{gdL}-1$ and $2345.8 \pm 1504 \mathrm{ml}$, respectively. It was observed from the medical records that none of the patients were transfused intraoperative platelet suspension. Intraoperative hourly urine output was measured in all patients and mean urine amount at the end of the operation was $636 \pm 560 \mathrm{ml}$. The comorbidities of patients are demonstrated in Table 2. A total of seven patients had comorbid diseases.

All the patients were anatomically reconstructed using fresh frozen allografts obtained following surgical resection. It was ascertained from the medical records that reconstruction methods, such as osteosynthesis, lumbopelvic stabilization, and total hip joint replacement arthroplasty were performed following residue pelvis, and prior to allografting.
Regional anesthesia was preferred as the anesthesia method in only two patients. CSE (combined spinal - epidural) anesthesia was performed using intrathecal bupivacaine $15 \mathrm{mg}$. From the medical records, it was learned that of the two cases with CSE, one had asthma and the other had congenital single kidney. Propofol, fentanyl, lidocaineand rocuroniumwereused for the induction of general anesthesia. $\mathrm{O} 2+\mathrm{N} 2 \mathrm{O}$ and sevoflurane $2 \%$ were selected for the maintenance of anesthesia. Internal jugular vein cannulation was performed in the patients who received general anesthesia and a large bore intravenous access was placed in patients who received regional anesthesia. There was no occurrence of intraoperative cardiac arrest in any of the patients.

The length of postoperative intensive care unit and hospital stay are detailed in Table 3. Postoperative intensive care unit stay was prolonged in three patients ( 48 hours in two patients and 144 hours in one patient). These three patients were among the four patients who had the largest amount of intraoperative bleeding. All the other patients were transferred from the intensive care unit to the orthopedics ward 24 hours postoperatively.

For postoperative analgesia, patient controlledepidural analgesia method was used in two patients who received combined spinalepidural anesthesia through the epidural catheter with bupivacaine $0.0125 \%$ and fentanyl $2 \mu \mathrm{g} \mathrm{mL}-1$. Intravenous patient control analgesia method using tramadol $10 \mathrm{mg} \mathrm{mL}$ 1 was used in ten patients who received general anesthesia.

It was understood from the hospital's database that six patients underwent reoperation following hemipelvectomy and reconstruction surgery. The duration of the first operation of the patients who underwent reoperation (322.6 643 minute) was significantly higher compared to those who had no reoperation $(225.0 \pm 52)$ 


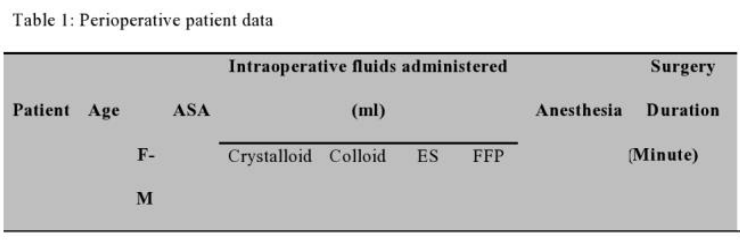

\begin{tabular}{|c|c|c|c|c|c|c|c|c|c|}
\hline 1 & 45 & M & 2 & 2800 & 1500 & 900 & 0 & GA & 310 \\
\hline 2 & 20 & M & 1 & 6200 & 1000 & 2500 & 900 & GA & 360 \\
\hline 3 & 42 & F & 2 & 3700 & 1000 & 2000 & 600 & GA & 300 \\
\hline 4 & 53 & F & 2 & 5500 & 1500 & 2500 & 600 & GA & 330 \\
\hline 5 & 23 & M & 2 & 3500 & 500 & 1250 & 0 & CSE & 246 \\
\hline 6 & 43 & F & 2 & 6000 & 1000 & 2500 & 300 & $\mathrm{GA}$ & 360 \\
\hline 7 & 43 & M & 3 & 6000 & 500 & 2000 & 600 & GA & 340 \\
\hline 8 & 31 & F & 2 & 2700 & 1000 & 750 & 300 & GA & 200 \\
\hline 9 & 53 & M & 2 & 3500 & 750 & 500 & 0 & CSE & 195 \\
\hline 10 & 57 & M & 2 & 1700 & 500 & 500 & 450 & GA & 195 \\
\hline 11 & 10 & M & 2 & 1400 & 0 & 350 & 0 & GA & 180 \\
\hline \multirow[t]{2}{*}{12} & 31 & M & 2 & 4000 & 500 & 2000 & 450 & GA & 270 \\
\hline & & & & $3916 \pm$ & $812 \pm$ & $1479 \pm$ & $350 \pm$ & & $273 \pm$ \\
\hline mean \pm & & & & 1672 & 441 & 855 & 302 & & 68 \\
\hline SD & & & & & & & & & \\
\hline
\end{tabular}

$(\mathrm{p}<0.05)$.Furthermore, the amount of intraoperatively administered fluids (3366.6 $\pm 1341 \mathrm{ml})$, in the first operation in the patients who underwent reoperation was found to be significantly higher compared to the intraoperative amount of fluids (1325.0 \pm 824 $\mathrm{ml})$ administered to the patients who had no reoperations $(\mathrm{p}<0.05)$.

Histopathological analyses of the internal hemipelvectomy specimens are seen in Table 4. It was noted that patients 1, 2 and 3 had received neoadjuvant radiotherapy, neoadjuvant chemotherapy and combined radiotherapy and chemotherapy, respectively. No statistical difference was found in the duration of postoperative intensive care stay and hospital stay between the patients who had or had not received neoadjuvant chemotherapy or radiotherapy $(\mathrm{p}>0.05)$.

It was established that mortality had occurred in five patients by the last date of follow-up (December 2014) due to reasons associated with their diseases. The causes of mortality were wound site problems, throumbusin the carotid artery and abdominal aorta, and postoperative respiratory failure due to lung metastasis in three patients.

Table 2: Comorbidities of the patients

\begin{tabular}{lc}
\hline Comorbidity & number \\
\hline Coronary artery disease & 2 \\
Hypertension & 1 \\
Diabetes Mellitus & 2 \\
Asthma & 1 \\
HBV & 7 \\
\hline Total & \\
\hline HBV: Hepatitis B antigen positivity in the serum of the patient
\end{tabular}

\section{DISCUSSION}

We believe that preoperative evaluation is as important as intraoperative and postoperative follow-up. Additionally, the preoperative evaluation should include an assessment of the effects of both the tumor and its treatment (9). Because cancer patients have some characteristic features that influence anesthetic management although there is no clear recommendation for either general or regional anesthesia. Findings that might have an influence on anesthesia, such as radiotherapy and chemotherapy treatments performed in this period, should be questioned and changes in the treatment site, vascular damage, and toxic effects on the heart and lungs should also be evaluated. Furthermore the necessary preparation of blood products should be planned with the blood bank, prior to the operation, in case of major blood loss during surgery. The mean intraoperative bleeding volume was $2345.8 \pm 1504 \mathrm{ml}$ in our cases. That shows that bleeding can be variable. The amount of blood loss might be very high, due to the presence of large tumors close to vascular structures and the necessity of large resections, large tissue dissection and the long duration of operations in hemipelvectomy and 
reconstruction surgery. Trauma to major pelvic vessels during surgery may result in severe blood loss, at a high rate and volume, due to tumors that block access to thevascular structures (4).

\begin{tabular}{lccc}
\multicolumn{3}{l}{ Tablo 3: Intensive care, hospital stay durations } \\
& $\mathbf{n}$ & median & $\min$ - $\max$ \\
\hline Intensive care time (hours) & 12 & 24 & $24-144$ \\
Hospital stay (days) & 12 & 19,5 & $7-84$ \\
\hline
\end{tabular}

Coagulopathy may be observed, due to the massive blood transfusions performed secondarily to massive blood loss. Freshfrozen plasma and platelet suspensions are transfused to treat the coagulopathy. Additionally, the monitoring of blood loss is challenging during the surgery. Majority of the blood loss remains obscure, due to surgical drapes and tampons, and even blood flow under the operation table. Due to the reasons stated above, normally large intravenous vascular access or central vein catheterization are required for blood and blood products. Blood loss in amounts close to that of the intraoperative bleeding may continue during the postoperative period. Decreasing the blood loss is important, since the infection risk is higher in patients with a greater amount of blood loss (10-12).

The controlled hypotension method, used in order to decrease blood loss, was notseen in this retrospective study. This was probably due to the difficulty in providing intraoperative hemodynamic stability. Cell saving methods are not used, due to the possibility of the infusion of neoplastic cells and the risk of metastatic disease (13). A condition that further challenges anesthesia management is that of cardiovascular collapse, whichmight bedue to the possibility of embolic particles passing into the pulmonary circulation.

Aprotinin as an antifibrinolytic agent has been studied in several studies including major orthopedic surgery. It could significantly reduce blood loss and blood transfusion requirements in patients undergoing major orthopedic surgery (14). But there are several

Adress for correspondence:

e-mail: dr.tugba.askin@gmail.com

Available at www.actaoncologicaturcica.com

Copyright $\odot$ Ankara Onkoloji Hastanesi conflicting reports in the literature for different surgery specialties regarding blood loss or transfusion (15-17). Aprotinin is not used in our clinic routinely for such major orthopedic surgery.

Table 4: Histopathological diagnosis

\begin{tabular}{lcc}
\hline Histopathology & M & 2 \\
\hline Ewing sarcoma & $\mathrm{M}$ & 3 \\
Osteosarcoma & $\mathrm{M}$ & 1 \\
Condrosarcoma & $\mathrm{M}$ & 2 \\
Malignant mesenchymal tumor & $\mathrm{B}$ & 1 \\
Giant cell tumor of the bone & $\mathrm{M}$ & 1 \\
Plasmocytoma & $\mathrm{B}$ & 1 \\
Cyst hydatid & $\mathrm{B}$ & $\mathbf{1 2}$ \\
\hline Desmoid tumor of the bone & & \\
\hline Total &
\end{tabular}

Pressure on the femoral canal, as seen in knee and hip arthroplasty and in intramedullary fixation surgery for femur fractures, causes the release of emboli containing vasoactive, inflammatory and thrombogenic substances into the circulation $(18,19)$. In a study of Molnar et al. it was reported that 16 of 49 cases experienced cardiovascular instability during periods of pressureon the femoral canal (4). We observed that ephedrine was used in doses of 5-15 mg in addition to the replacement of intravenous fluid and blood products for the treatment of intraoperatively developed hypotension in 7 out of 12 cases that we analyzed. Nevertheless, no inotropic agents were administered during the operation. Providing a preemptive normovolemia in this critical period, increasing the amount of inspired oxygen and decreasing the depth of applied anesthesia volatile agents etc. or vasodilating drugs, might be helpful (9). Following general anesthesia, no patients required mechanical ventilation in the surgical intensive care unit postoperatively 
afterextubation. It was observed that paracetamol and nonsteroidal antiinflammatory agents were used, particularly in the early postoperative period, in addition to epidural and intravenous patient controlled analgesia methods, for postoperative pain management.

Postoperative day 1 International Normalized Ratio (INR), prothrombin time (PT), and Activated Partial Thromboplastin Time (aPTT) values in the patients with epidural catheters were found to be within acceptable limits. It was also observed that no neurological complications were recorded in the two patients who had undergone regional anesthesia. Our study may have several limitations since it is just a basic type of descriptive andretrospective study. Another limitation of the study wassmall sample size. Additionally, the anesthetic method may vary according to the individual preference and experience of the anesthesia providers at our institution.

\section{Conclusion}

Anesthesia management in hemipelvectomy and reconstruction surgery is a challenging process, due to the unpredictable amount of bleeding and the long duration of surgery, and in terms of follow-up. According to our studies, it can be established that the control and follow-up of bleeding, the resuscitation of appropriate fluids and blood products, are the interventions generally performed in these cases.

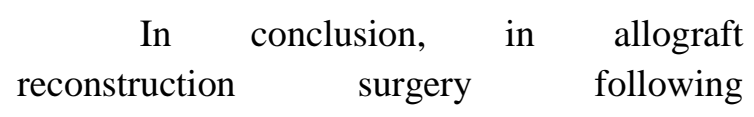
hemipelvectomy, accurate evaluations starting in the preoperative period should be continued with close hemodynamic follow-up during the operation and also in the postoperative period. Due to these reasons, communication and collaboration of anesthesia, surgery, blood bank and postoperative intensive care unitsare important.
Acknowledgments: The authors declared that this study has received no financial support.

\section{REFERENCES}

1. Mankin HJ, Doppelt S, Tomford W. Clinical experience with allograft implantation. The first ten years. ClinOrthopRelat Res 1983; 174: 69 - 86.

2. Langlais F, Lambotte JC, Thomazeau H. Long-term Results of Hemipelvis Reconstruction With Allografts. ClinOrthopRelat Res 2001; 388: 178 - 86.

3. Carter SR, Eastwood DM, Grimer RJ, Sneath RS. Hindquarter amputation for tumors of the musculoskeletal system. J Bone Joint Surg Br 1990; 72: 490 - 493.

4. R. Molnar, G. Emery, P. F. Choong. Anaesthesia for hemipelvectomy - a series of 49 cases. Anaesthesia and Intensive Care 2007; 35: 536 - 543.

5. Couto A.G.H, Araújo B., Vasconcelos R.A.T., RenniM.J., Fonseca C.O.,Cavalcanti I.L.. Survival rate and perioperative data of patients who have undergone hemipelvectomy: a retrospective case series. World Journal of Surgical Oncology 2016; 14:255.

6. Flóris I, Bodzay T, Vendégh Z, Gloviczki B, Balázs P. Short - term results of total hip replacement due to acetabular fractures. Eklem Hastalik Cerrahisi 2013; 24: $64-71$.

7. Apffelstaedt JP, Karakousis CP. Partialand Complete Internal Hemipelvectomy: Complications and Long Term Follow up. J Am Coll Surgery 1995;181:43-48

8. Karakousis CP, Emrich LJ, Driscoll DL. Variants of Hemipelvectomy and Their Complications. Am J Surg 1989;158(5):404-408.

9. Monedero P1, Calderón R, Moreno-Jiménez M, Aramendía JM, Otero M. Anesthesia for the patient with cancer. Rev Esp Anestesiol Reanim 2001 Nov; 48: 423 433.

10. Tan MH, Mankin HJ. Blood transfusion and bone allografts. Effect on infection and outcome. ClinOrthopRelat Res. 1997 Jul; 340: 207 - 14.

11. Lopez - Sosa FH, Polly D, Bowen JR, Eppes SC, Klein JD, St John KH, et al. Serum Cefazolin Levels During Spinal Fusion: Effect of Blood Loss and Duration of Surgery. J Spinal Disord 1993; 6: 296 - 299.

12. Öztürk R, Aydın M, Arıkan M, Toğral G, Aydın G, Güngör BŞ. The report of tumor resection prosthesis infection due to Sphingomonas paucimobilis. Acta Oncol Tur 2016; 49(1): 57-60

13. Hansen E, Wolf N, Knuechel R. Tumour cells in bloodshed from the surgical field. Arch. Surg 1995; 130: $387-393$.

14. Huang F, Zhao Q, Guo C, Ma G, Wang Q, Yin Y, et al. Use of aprotinin to reduce blood loss and transfusion in major orthopedic surgery: a meta-analysis. Transfusion and Apheresis Science 2014; 51: 152 - 161.

15. Fergusson DA, Hebert PC, Mazer CD, et al. A comparison of aprotininand lysine analogues in high-risk cardiac surgery. N Engl J Med2008; 358: 2319-2331.

16. Massicotte L, Denault AY, Beaulieu D, Thibeault L, Hevesi Z, Roy A. Aprotinin versus tranexamic acid during liver transplantation: impact on blood product requirements and survival. Transplantation2011; 91: 1273-1278. 
17. Ickx BE, van der Linden PJ, Melot $\mathrm{C}$, et al. Comparison of the effectsof aprotinin and tranexamic acid on blood loss and red blood celltransfusion requirements during the late stages of liver transplantation.Transfusion 2006; 46: 595605

18. Dahl OE. Cardiorespiratory and vascular dysfunction related to major reconstructive orthopedic surgery. ActaOrthopScand 1997; 68: 607 - 614.
19. Modig J, Busch C, Olerud S, Saldeen T, Waernbaum G. Arterial hypotension and hypoxaemia during total hip replacement: the importance of thromboplastic products, fat embolism and acrylicmonomers. Acta Anaesthesiol Scand 1975; 19: 28 - 43 . 